\title{
GUIDELINES FOR AUTHORS
}

The Australian Journal of Indigenous Education is a peer reviewed research journal publishing articles in the field of Indigenous education, broadly defined. It is the only journal for educators devoted specifically to issues of practice, pedagogy and policy in Indigenous education in Australia. The journal has an international audience and is highly valued by its readers as a reliable source of information on Indigenous education issues.

Manuscripts may be accepted for publication, returned for revision or rejected. However, every effort will be made to help authors bring their manuscript up to the required standard for publication. Minor amendments may be made by editorial staff following review to ensure that reasonable standards of content, presentation and readability are maintained. The editors' decision is final.

In addition to the above, Australian Journal of Indigenous Education welcomes brief reports (500-1500 words) on program development, policy development or research. Acceptance for publication will be on the basis of review by the editorial team.

COPYRIGHT: It is a condition of publication that copyright is assigned by the author(s) to the publisher. Copyright assignment forms will be sent to authors on receipt of their papers.

\section{GENERAL STYLE GUIDELINES}

1. Contributions should follow the format and style described in the Publication Manual of the American Psychological Association (6th ed). Spelling and punctuation should conform to The Macquarie Dictionary (5th ed). For matters of style not covered in these two publications, the Style Manual for authors, editors and printers (6th ed) should be consulted.

2. Uncommon abbreviations and acronyms should be explained. Do not use underlining except to indicate italics. Full stops should not be used in abbreviations or acronyms (e.g., NSW).

3. Use single quotation marks to introduce a word or phrase used as an ironic comment, as slang, or which has been coined. Use quotation marks the first time the word or phrase is used; do not use them again.

Do not use quotation marks to introduce a technical or key term. Instead, italicise the term.

4. Do not use any footnotes. Endnotes should be kept to a minimum and listed at the end of the text under the centred heading 'Endnotes'. Acknowledgments should be placed at the end of the article with a separate heading.

5. A list of figure captions should follow the tables in the manuscript.
6. References should follow the format and style described in the Publication Manual of the American Psychological Association (6th ed).

\section{Examples of citations are:}

The theory was first propounded in 1970 (Larsen, 1971). Larsen (1971) was the first to propound the theory.

\section{Examples of references are:}

Larson, P.J., \& Maag, J.W. (1998). Applying functional assessment in general education classrooms. Issues and recommendations. Remedial and Special Education, 19, 338-349.

Sheridan, S.M. (1998). Social skills training for ADHD children. In S. Goldstein \& M. Goldstein, (Eds.), Managing attention deficit hyperactivity disorder in children (pp. 592-612). New York: John Wiley.

\section{AUTHOR MANUSCRIPT CHECKLIST}

Please ensure the following are included in your submission:

- first name and surname of all authors

- affiliations (institution and country) of all authors

- name and full postal and e-mail address of the corresponding author

- running head of maximum 50 characters including spaces

- up to 6 keywords

- abstract of no more than 250 words in length

- the approximate positions of all tables and figures mentioned in the text indicated by the words 'Insert Table/ Figure $\mathrm{X}$ about here'

- APA style for citations, references, numbers, capitalisation, table and figure captions, and statistical symbols

- all figures supplied separate to text in PDF format, NOT in colour, and clearly readable.

Any enquiries should be addressed to:

Managing Editor

The Australian Journal of Indigenous Education

Aboriginal and Torres Strait Islander Studies Unit

The University of Queensland

Brisbane QLD 4072

AUSTRALIA

Email: ajie@uq.edu.au

URL: https://www.cambridge.org/core/journals/ australian-journal-of-indigenous-education

Manuscripts must be submitted via the peer-review system: http://mc.manuscriptcentral.com/ajie 


\section{The Australian Journal of}

\section{INDIGENOUS EDUCATION}

\section{Part 1: Special Issue}

Editorial December 2020

Martin Nakata, Bronwyn Fredericks and Katelyn Barney

Introduction to the special issue: critical conversations on higher education as an enabler to building an Indigenous health workforce

Chelsea Bond and Helena Kajlich

Addressing the knowledge gap of Indigenous public health: reflections from an Indigenous public health graduate Natasha Lee

... but what about the Aboriginal and/or Torres Strait Islander Health Worker academic? Transcending the role of 'unknowing assistant' in health care and research through higher education: a personal journey Janet Stajic

Embodied Indigenous knowledges protecting and privileging Indigenous peoples' ways of knowing, being and doing in undergraduate nursing education Ali Drummond

'It wasn't just the academic stuff, it was life stuff': the significance of peers in strengthening the Indigenous health researcher workforce

Tess Ryan, Shaun Ewen and Chris Platania-Phung
Racial complaint and sovereign

108

divergence: the case of Australia's first Indigenous ophthalmologist

David Singh

Looking forward looking black: making the case for a radical rethink of strategies for success in Indigenous higher education Chelsea Bond, Mark Brough, Bryan Mukandi, Shannon Springer, Deborah Askew and Janet Stajic

Part 2: A dialogue about the role of Direct Instruction (DI) in very remote schools

Did DI do it? The impact of a programme designed to improve literacy for Aboriginal and Torres Strait Islander students in remote schools John Guenther and Samuel Osborne

Direct Instruction in very remote schools: a rejoinder to Guenther and Osborne (2020) Jennifer Buckingham

Did DI do it? Response to a rejoinder John Guenther and Samuel Osborne 